\title{
MASALAH KARIES GIGI DENGAN KUALITAS HIDUP PADA ANAK USIA 5-7 TAHUN DI KECAMATAN LANDASAN ULIN KOTA BANJARBARU KALIMANTAN SELATAN
}

\author{
DENTAL CARE PROBLEMS WITH QUALITY OF LIFE IN CHILDREN AGES 5-7 \\ YEARS OLD IN LANDASAN ULIN DISTRICT, BANJARBARU CITY, SELATAN \\ KALIMANTAN
}

\author{
Bunga Nurwati*1, Darmawan Setijanto ${ }^{2}$ \\ ${ }^{1}$ Poltekkes Kemenkes Banjarmasin. \\ Jalan Mistar Cokrokusumo. Banjarbaru Kalimantan Selatan. Indonesia \\ 2 Fakultas Kedokteran Gigi Universitas Airlangga, Surabaya \\ Jalan Prof.Dr.Moestopo No. 24. Surabaya. Indonesia \\ *Email: aisyahhumairo79@gmail.com
}

\begin{abstract}
The 2010 dental health service targets that have been determined by WHO include 90\% of children aged 5 years free of caries and children aged 12 years having a tooth decay severity of 1 (one) tooth. Nationally, the DMF-T Index in 2013 was 4.6. This shows that the average tooth decay in the Indonesian population is 5 teeth per person. This study aims to determine the number of dental caries and quality of life in children aged 5-7 years in Landasan Ulin District, Banjarbaru City, South Kalimantan. The research method used was analytic observational with design cross-sectional. The population is all children aged 5-7 years in Landasan Ulin District, Banjarbaru City. The research sample was 138 children aged 5-7 years. Data collection using the ECOHIS questionnaire and examination of children's teeth. The results showed that the high number of dental caries experienced by children aged 5-7 years was around $66.65 \%$ with a mean deft of 9.05. The results of the measurement of the ECOHIS questionnaire showed that around $44.2 \%$ of children with dental caries often found it difficult to drink hot or cold drinks and about $27.5 \%$ of children did not attend a school or were not deposited in daycare centers. In this study, it can be concluded that dental caries in children can interfere with the quality of life.
\end{abstract}

Keywords: dental caries; quality of life; ECOHIS

\begin{abstract}
ABSTRAK
Target pelayanan kesehatan gigi 2010 yang telah ditentukan oleh WHO antara lain 90\% anak umur 5 tahun bebas karies dan anak umur 12 tahun mempunyai tingkat keparahan kerusakan gigi sebesar 1 (satu) gigi. Secara nasional Indeks DMF-T pada tahun 2013 sebesar 4,6. Hal ini menunjukkan rerata kerusakan gigi pada penduduk indonesia 5 buah gigi perorang.. Penelitian ini bertujuan untuk mengetahui angka karies gigi dengan kualitas hidup pada anak usia 5-7 tahun di Kecamatan Landasan Ulin Kota Banjarbaru Kalimantan Selatan. Metode penelitian yang digunakan adalah observasional analitik dengan rancangan cross sectional. Populasi adalah seluruh anak usia 5-7 tahun di Kecamatan Landasan Ulin Kota Banjarbaru. Sampel penelitian sebesar 138 anak usia 5-7 tahun. Pengumpulan data dengan menggunakan kuesioner ECOHIS dan pemeriksaan gigi geligi anak. Hasil penelitian menunjukkan bahwa tingginya angka karies gigi yang dialami anak usia 5-7 tahun sekitar $66,65 \%$ dengan rerata def-t sebesar 9,05. Hasil pengukuran kuesioner ECOHIS diperoleh angka sekitar $44,2 \%$ anak yang mengalami karies gigi sering merasa kesulitan minum minuman panas atau dingin dan sekitar $27,5 \%$ anak tidak masuk sekolah atau tidak dititipkan di tempat penitipan. Pada penelitian ini dapat disimpulkan bahwa karies gigi pada anak dapat mengganggu kualitas hidup.
\end{abstract}

Kata Kunci: Karies gigi; Kualitas hidup; ECOHIS 


\section{PENDAHULUAN}

Target pencapaian pelayanan kesehatan gigi 2010 yang telah ditentukan oleh World Health Organization antara lain anak umur 5 tahun $90 \%$ bebas karies dan anak umur 12 tahun mempunyai tingkat keparahan kerusakan gigi (indeks DMF-T) sebesar 1 (satu) gigi. Indeks DMF-T secara nasional pada tahun 2013 sebesar 4,6. Hal ini menunjukkan rerata kerusakan gigi pada penduduk indonesia 5 buah gigi perorang. $(10,11)$. Data yang diperoleh dari Persatuan Dokter Gigi Indonesia (PDGI) menyebutkan bahwa $89 \%$ penderita gigi berlubang adalah anak usia dibawah 12 tahun (19). Prevalensi karies gigi untuk gigi sulung pada anak sebesar $80 \%$ dengan rerata def-t 5,0 dan sekitar $70 \%$ karies gigi untuk gigi permanen pada anak dengan rerata DMF$\mathrm{T}$ 3,5 (2). Beberapa penelitian menunjukkan adanya angka karies gigi pada anak sekolah dengan rerata DMF-T sebesar 3,71 yang artinya anak sekolah mengalami karies gigi dengan rerata 4 gigi peranak. Adanya kejadian karies yang cukup tinggi ditemukan pada anak usia sekolah 8-12 tahun yaitu sebesar $84,0 \%$ dengan rerata 2,6 kategori sedang $(8,23)$.

Anak usia sekolah khususnya anak Sekolah Dasar merupakan satu kelompok yang rentan terhadap penyakit gigi dan mulut karena umumnya anak tersebut masih mempunyai perilaku atau kebiasaan diri yang kurang menunjang terhadap kesehatan gigi (17). Pengalaman karies gigi sangat tinggi diantara anak Sekolah Dasar khususnya kelas pertama, dan sebagian besar karies gigi tersebut tidak dirawat (3). Hasil penilitian mengatakan bahwa kebanyakan dampak atau gangguan berhubungan dengan kesulitan makan dan status emosional pada anak. Sakit gigi, gigi berlubang dan gigi sensitif adalah penyebab gangguan yang paling banyak dialami. Rerata ganguan tidur/aktivitas terdapat pada anak dengan karies tertinggi dan rerata gangguan aktivitas sosial terdapat pada anak dengan kondisi OHI-S yang jelek (9).

Penelitian lain juga mengatakan hal yang serupa bahwa karies yang sudah lanjut dapat mempengaruhi kesehatan dan kualitas hidup seseorang yang menyebabkan rasa sakit, sulit tidur dan makan, menurunnya indeks massa tubuh, tidak masuk sekolah bahkan rawat inap serta biaya yang dikeluarkan untuk pengobatan karies yang parah lebih tinggi daripada kasus lesi yang awal. Keadaan mulut yang buruk, misalnya banyaknya gigi hilang sebagai akibat gigi rusak atau trauma yang tidak dirawat, akan mengganggu fungsi dan aktivitas rongga mulut sehingga akan mempengaruhi status gizi serta akan mempunyai dampak pada kualitas hidup. Mashoto dan kawan-kawan menyatakan bahwa status kesehatan mulut berhubungan erat dengan kualitas hidup. Tindakan promotif dan preventif merupakan kontribusi terbesar dalam kedokteran gigi untuk meningkatkan kualitas hidup (14).

Sajadi dan kawan-kawan mengatakaan bahwa kesehatan gigi dan mulut anak memiliki dampak yang signifikan pada kualitas hidup anak dan orang tua (18). Dampak kualitas hidup ini lebih berpengaruh pada anak dari pada orang tua. Dampak karies gigi ketika skor DMF-T tinggi, dapat dihubungkan dengan gangguan kualitas hidup dikarenakan adanya ketidakmampuan proses pengunyahan, serta tidur dan kosentrasi terganggu yang diakibatkan oleh sakit gigi yang diderita individu baik orang dewasa maupun anak. Gangguan kualitas hidup ini dipengaruhi oleh lesi dentin dan gigi berlubang yang tidak diobati $(13,21)$. Early Childhood Oral Health Impact Scale (ECOHIS) merupakan parameter untuk menilai dampak atau gangguan Oral Health Quality of Life (OHQoL) baik anak maupun orang tua $(16,20)$. Lesi dentin dan gigi berlubang yang tidak diobati dapat mempengaruhi kualitus hidup anak (13). Penelitian ini bertujuan untuk mengetahui angka karies gigi pada anak usia 5-7 tahun dengan gangguan rasa nyeri yang diakibatkan oleh karies gigi.

\section{BAHAN DAN METODE}

Metode yang digunakan adalah observasional analitik dengan rancangan penelitian cross sectional. Variabel penelitian adalah karies gigi dan kualitas hidup. Populasi penelitian adalah seluruh anak usia 5-7 tahun di Kecamatan Landasan Ulin Kota Banjarbaru. Tehnik pengambilan sampel menggunakan purposive sampling. Lokasi pengambilan sampel di TK. Aisiyah Bustanul Atfal

Golf sebanyak 46 orang anak berusia 5 tahun dan SDN 2 Syamsudin Noor sebanyak 92 orang anak. 
Analisis yang digunakan adalah analisis proporsi atau persentase.

\section{HASIL DAN PEMBAHASAN}

Tabel 1. Distribusi frekuensi karies gigi anak usia 5-7 tahun

\begin{tabular}{|c|c|c|}
\hline Variabel & $\mathbf{n}$ & (\%) \\
\hline \multicolumn{3}{|l|}{ Def } \\
\hline Rendah & 18 & 13,04 \\
\hline Sedang & 28 & 20,28 \\
\hline Tinggi & 95 & 66,65 \\
\hline Rerata def & \multicolumn{2}{|c|}{9.05} \\
\hline \multicolumn{3}{|l|}{ DMF } \\
\hline Rendah & 138 & 100 \\
\hline Sedang & 0 & 0 \\
\hline Tinggi & 0 & 0 \\
\hline Rerata DMF & \multicolumn{2}{|c|}{0.24} \\
\hline
\end{tabular}

Tabel 1. menggambarkan karakteristik status karies gigi pada anak usia 5-7 sangat tinggi. Pada tabel tersebut terlihat bahwa sebagian besar anak usia 5-7 tahun mengalami karies gigi yang cukup parah atau sekitar $66,65 \%$ dan hanya $13,04 \%$ anak usia 5-7 tahun mengalami karies yang rendah. Rerata def-t menggambarkan bahwa dalam rongga mulut anak usia 5-7 tahun mengalami karies gigi sebanyak 9 gigi peranak. Gambaran DMF sangatlat rendah pada tabel tersebut. Hal ini disebabkan adanya gigi bercampur pada anak usia 5-7 tahun.

Tabel 2. Distribusi frekuensi antara karies gigi dengan gangguan fungsional pada anak usia 5-7 tahun.

\begin{tabular}{|c|c|}
\hline Variabel & Gangguan Fungsional \\
\hline \multirow{3}{*}{$\begin{array}{l}\text { Karies } \\
\text { gigi }\end{array}$} & $\mathrm{TP}(\%)$ \\
\hline & $\begin{array}{l}\text { Kesulitan minum minuman panas } \\
\text { atau dingin }\end{array}$ \\
\hline & $77(55,8 \%)$ \\
\hline \multirow{2}{*}{$\begin{array}{l}\text { Karies } \\
\text { gigi }\end{array}$} & Kesulitan makan beberapa makanan \\
\hline & $53(38,4 \%)$ \\
\hline \multirow{2}{*}{$\begin{array}{l}\text { Karies } \\
\text { gigi }\end{array}$} & Kesulitan dalam berbicara \\
\hline & $102(73,9 \%)$ \\
\hline \multirow[t]{2}{*}{$\begin{array}{l}\text { Karies } \\
\text { gigi }\end{array}$} & $\begin{array}{l}\text { Tidak masuk sekolah dan tempat } \\
\text { penitipan anak }\end{array}$ \\
\hline & $100(72,5 \%)$ \\
\hline
\end{tabular}

Tidak pernah (TP), Sangat sering (SS)

Tabel 2. menunjukkan bahwa pada sub skala kesulitan minum minuman panas atau dingin dikarenakan karies gigi terlihat sekitar 44,2\% atau sebanyak 61 orang anak yang mengalami karies gigi sering merasa kesulitan minum minuman panas atau dingin. Namun sekitar 55,8\% atau sebanyak 77 orang anak tidak pernah merasa kesulitan minum minuman panas atau dingin dikarenakan masalah gigi atau karies gigi. Pada sub skala kesulitan makan beberapa makanan dikarenakan masalah gigi atau karies gigi menunjukkan bahwa sekitar $38,4 \%$ atau sebanyak 53 orang anak yang mengalami karies gigi sangat sering merasa kesulitan makan beberapa makanan. Sekitar $61,6 \%$ atau sebanyak 85 orang anak usia 5-7 tahun tidak pernah mengalami kesulitan makan beberapa makanan. Pada sub skala kesulitan berbicara terlihat sekitar $73,9 \%$ atau sebanyak 102 orang anak yang mengalami karies gigi tidak pernah mengalami kesulitan berbicara dan sekitar $26,1 \%$ atau sebanyak 36 orang anak sering mengalami kesulitan dalam berbicara. Pada sub skala tidak masuk sekolah dan tempat penitipan terlihat sekitar $72,5 \%$ atau sekitar 100 orang anak yang mengalami karies gigi tidak pernah absen sekolah dan absen pada tempat penitipan anak dikarenakan masalah gigi atau karies gigi dan hanya 27,5\% atau sebanyak 38 orang anak yang mengalami karies gigi sangat sering absen sekolah dan absen pada tempat penitipan anak dikarenakan masalah gigi.

\section{PEMBAHASAN}

Hasil penelitian karies gigi dengan kualitas hidup pada anak usia 5-7 tahun di Kecamatan Landasan Ulin Kota Banjarbaru di peroleh bahwa angka karies gigi yang diukur menggunakan indeks def-t masih sangat tinggi pada anak usia 5-7 tahun (Tabel.1), dan angka karies gigi yang diukur dengan indeks DMF sangat rendah. Hal ini disebabkan masih adanya gigi bercampur pada rongga mulut anak pada usia tersebut. Selain adanya periode gigi bercampur, perilaku dan kebiasaan pada anak juga merupakan salah satu faktor penyebab tingginya angka karies gigi. Banyak makan dan minum serta tidak memperhatiakn kebersihan mulut dapat meyebabkan gigi mudah terserang karies pada anakanak dibanding orang dewasa (4). Pola konsumsi kariogenik yang tinggi seperti coklat, roti dan permen merupakan salah satu penyebab terjadinya karies gigi. Sifat makanan kariogenik banyak mengandung karbohidrat dan mudah lengket

sehingga dengan mudah bakteri merubah gula menjadi asam dan pada akhirnya menjadi karies gigi (5). Anak usia sekolah lebih senang mengkonsumsi makanan kariogenik dibandingkan makanan yang 
tidak menyebabkan karies gigi, misalnya buahbuahan (1).

Resiko gigi berlubang pada anak dapat meningkat dengan cepat bila pola makan pada anak tidak dikontrol seperti mengkonsumsi makanan manis yang mudah melekat pada permukaan gigi dan makan penganan diluar waktu makan. Hal ini dapat meningkatkan pertumbuhan bakteri dalam mulut yang kemudian mengakibatkan peningkatan asam yang akan mempercepat terjadinya lubang pada gigi (19).

Tingginya karies gigi pada anak dapat menyebabkan status kesehatan gigi dan mulut yang jelek. Karies gigi dapat menimbulkan rasa sakit, baik pada gigi, mulut maupun rahang. Apabila invasi bakteri sudah sampai ke pulpa gigi yang terdiri dari pembuluh darah dan syaraf gigi, maka terjadi infeksi pada pulpa yang menyebabkan rasa sakit yang berdenyut sehingga dapat mempengaruhi aktivitas dan fungsi fisiologis serta psikologis pada anak $(7,12)$. Karies gigi juga berdampak pada timbulnya rasa sakit serta kesulitan dalam melakukan aktivitas sehari-hari. Mayoritas rasa sakit yang diakibatkan oleh karies gigi adalah kesulitan makan, menggosok gigi, tidur, bermain dan pergi kesekolah (15).

Pada tabel 2. Variabel karies gigi dengan dimensi gangguan fungsional menunjukkan bahwa gangguan fungsional khusunya pada sub skala kesulitan minum minuman panas atau dingin terlihat sekitar $44,2 \%$ atau sebanyak 61 orang anak sering mengalami gangguan pada sub skala ini dan 38,4\% atau sebanyak 53 orang anak yang mengalami karies gigi sangat sering merasa kesulitan makan beberapa makanan. Pada sub skala gangguan kesulitan berbicara dan tidak masuk sekolah dan tempat penitipan hanya $26.1 \%$ dan $27.5 \%$ yang sering mengalami gangguan pada kedua sub skala tersebut. Hal ini disebabkan oleh karena kondisi keadaan mulut yang buruk, misalnya banyaknya gigi hilang sebagai akibat gigi rusak atau trauma yang tidak dirawat, sehingga mengganggu fungsi dan aktivitas rongga mulut dalam proses pengunyahan. Gangguan

fungsional ini juga berdampak pada proses penyerapan makanan yang akan mempengaruhi status gizi dan perkembangan yang berakibat pada kualitas hidup anak tersebut $(5,9)$.
Anak-anak dengan status kesehatan mulut yang buruk lebih memungkinkan untuk mengalami rasa sakit pada gigi, bolos sekolah serta mengganggu kinerja anak disekolah. Penelitian Stephani dan kawan-kawan mengatakan bahwa anak-anak kehilangan rata-rata separuh hari sekolah dikarenakan alasan yang berkaitan dengan masalah perawatan gigi, dan 17\% ketidakhadiran anak-anak disekolah disebabkan adanya rasa nyeri dan infeksi pada gigi dan mulut (22).

Penelitian lain juga mengatakan bahwa karies gigi memiliki dampak pada aktifitas belajar anak, tetapi tidak ada hubungan antara ketidakhadiran maupun gangguan prestasi belajar yang disebabkan oleh masalah gigi dan mulut (6). Diharapkan dengan status kesehatan gigi dan mulut yang baik dapat menunjang pendidikan dan prestasi anak disekolah.

\section{KESIMPULAN DAN SARAN}

Kesimpulan pada penilitian ini adalah tingginya angka karies gigi pada anak usia 5-7 tahun dan menyebabkan beberapa gangguan fungsional seperti kesulitan minum, makan, berbicara dan kesulitan mengikuti proses belajar dibangku sekolah. Saran penelitian ini diharapkan adanya kerjasama lintas sektoral dalam rangka upaya penurunan angka karies gigi pada anak berupa upaya promotif, preventif dilingkungan sekolah baik Taman kanakkanak maupun Sekolah Dasar.

\section{UCAPAN TERIMAKASIH}

Ucapan terima kasih pada pihak Sekolah TK. Aisiyah Bustanul Atfal Golf Landasan Ulin dan SDN 2 Syamsudin Noor Landasan Ulin Kota Banjarbaru Kalimantan Selatan yang telah memberikan ijin untuk dilakukan penelitian.

\section{DAFTAR PUSTAKA}

1. Adimayanti, E, Haryani, S, Rosidi A, 2013. Hubungan Antara Konsumsi Makanan Kariogenik Dengan Kejadian Karies Gigi Pada Anak SDN 1 Gogodalem, Kec. Bringin, Kab. Semarang. e-Jurnal UNIMUS. Vol.2, No.1.

2. Al Agili DE, 2012. A systematic review of pulation-based dental caries studies among 
children in saudi arabia. The Saudi Dental Journal (2013) 25, 311.

3. Ambarkova, V, Apostolova, D, Gothe, RM, 2014. Dental Caries Experience Among 5 Year Age Children From Two Municipalities Berovo and Pechcevo In The Eastern Region of The Republic of Macedonia. Journal of Dental Applications. Vol.1 (4). 61-67.

4. Arisman., 2007. Gizi Dalam Daur Kehidupan, Jakarta, EGC.

5. Baginska, J., 2013. Evaluation of the Status of Primary Dentition in 6-7-Year-Old Children from Bialystok District Using the Mean $\mathrm{dmf}$ and the Index of Clinical Consequences of Untreated Caries (pufa). Dent. Med. Probl. 2013, 50, 2, 160 166

6. El-Sayyed, M.H., Khadiga, H.O., Al-Bashir, I. ElNour., 2015. Prevalence of Dental Caries and its Impact on the Academic Performance of Sudanese Basic School Children, Al-Sahafa Residental Area (2013-2014). Journal of American Science 2015:11(4).

7. Haditono S, Monks F, Knoers A. Psikologi Perkembangan. Yogyakarta. Gadjah Mada University Press. 2006;262-269.

8. Hanapi, AN. 2014. Angka Kejadian Karies dan Gingivitis Pada Anak Sekolah Dasar Usia 8-12 Tahun di Kabupaten Maros Tahun 2014. Skripsi. Universitas Hasanuddin, FKG. Makassar

9. Hartika, DM. 2011. Gambaran Kualita Hidup Anak usia 10-11 Tahun Berdasarkan Status Kesehatan Mulut. Skripsi. Universitas Hasanuddin, FKG. Makassar.

10. Kemenkes, 2007., Riset Kesehatan Dasar, Badan Penelitian dan Pengembangan, Kementrian Kesehatan Republik Indonesia.

11. Kemenkes, 2013., Riset Kesehatan Dasar, Badan Penelitian dan Pengembangan, Kementrian Kesehatan Republik Indonesia.

12. Kidd EAM, Bechal SJ. 2013. Dasar-Dasar Karies Penyakit dan Penanggulangannya. Alih Bahasa. Suwaminata, N dan Yuwono, L. EGC, Jakarta.

13. Leal SC, Bronkhorts EM, Fan M, Frencken, JE. 2012. Untreated Cavitated Dentin Lesions: Impact on Children's Quality of Life. Caries Res 46:102-106.

14. Mashoto, K., Astrom, AN., Johanson, AK., Masalu J., 2009. Effect Basic Oral Care Servis on
Oral Quality of Life of Primary Schoolchildren in Kilwa District Tanzania, University of Berden, Tanzania.

15. Moure-leite, F.R., Ramos-Jorge, J., Ramos-Jorge, M.L., Paiva, S.M., Vale, M.P., Pordeus, I.A., 2011. Impact of Dental Pain on Daily Living of Five-Year-Old Brazilian Preschool Children: Prevalence and Associated Factor. J. Eur Arch. Paediatr Dent. 2011, Dec; 12(6) 293-7.

16. Pahel BT, Rozier RG, Slade GD, 2007. Parental Perceptions of Children's Oral Health: The Early Childhood Oral Health Impact Scale (ECOHIS). Health and Quality of Life Outcomes. BioMed Central 5:6.

17. Pontonowu, J, Mariati, Ni W, Wicaksono, DA, 2013. Gambaran Status Karies Anak Sekolah Dasar di Kelurahan Kinilow 1 Kecamatan Tomohon Utara. Jurnal e-Gigi Juli-Desember. Vol 1. No.2

18. Sajadi FS, Pishbin L, Azhari SH, Moosazadeh M, 2015. Impact of Oral and Dental Health on Children's and Parents' Quality of Life Based on Early Childhood Oral Health Impact Scale (ECOHIS) Index. International Journal of Dental Sciense and Research. Vol. 3, No. 2, 28-31.

19. Sariningsih, E, 2013. Merawat Gigi Anak Sejak Usia Dini. PT. Elex Media Komputindo. Jakarta.

20. Scarpelli, AN, Oliveira, BH, Tesch, FC, Leao, AT, Pordeus, IA, Paiva, SM, 2011. Psychometric properties of the Brazilian version of the Early Childhood Oral Health Impact Scale (BECOHIS). BMC Oral Health. Vol.11:9.

21. Sischo, L dan Border, HL, 2011. Oral HealthRelated Qualit y of Life, What, Why, How and Future implications. J. Dent Res 90 (11):12641270

22. Stephani, L.J., William, F.Vann Jr., Jonathan B. Kotch., Bahuna, T. Pahel., Jessica Y. Lee., 2011. Impact of Poor Oral Health on Children's School Attendance and Performance. Am.J. Public Health, 2011. October 101(10):1900-1906.

23. Worotitjan I, Mintjelungan CN, Gunawan P. 2013. Pengalaman Karies Gigi Serta Pola Makan dan Minum Pada Anak Sekolah Dasar di Desa Kiawa Kecamatan Kawangkoan Utara. Jurnal eGIGI (eG). Vol.1 Maret 2013. Hlm.59-68. 